\title{
Peranan PPAT Dalam Pembuatan Akta Peralihan Hak Atas Tanah Dan/Atau Bangunan Bekas Hak Milik Adat Berkaitan Dengan Pembayaran Bea Perolehan Hak Atas Tanah Dan/Atau Bangunan
}

\author{
Eko Puji Hartono*, Akhmad Khisni**

* Mahasiswa Program Magister (S2) Kenotariatan Fakultas Hukum UNISSULA, Semarang email :
** ekopujihartono@gmail.com
Dosen Fakultas Hukum UNISSULA

\begin{abstract}
ABSTRAK
BPHTB adalah pajak yang dikenakan atas peralihan hak atas tanah dan/atau bangunan, yang mengakibatkan terjadinya peralihan hak atas tanah dan/atau bangunan dari yang mempunyai hak kepada yang memperoleh hak atas tanah dan/atau bangunan, sedangkan hak atas tanah adalah sebagaimana yang dimaksud dalam UndangUndang Nomor 5 Tahun 1960 tentang Peraturan Dasar Pokok-Pokok Agraria. Untuk membuktikan adanya peralihan hak atas tanah dan/atau bangunan kecuali pemindahan hak melalui lelang, sebagaimana yang dikehendaki UUPA harus dibuktikan dengan akta otentik yang dibuat oleh PPAT.Sebagai salah satu Pejabat yang berwenang untuk membuat akta peralihan hak aias tanah dan/atau bangunan, PPAT tunduk pada ketentuan Pasal 91 ayat (1)Undang-Undang Nomor 28 Tahun 2009 tentang Pajak Daerah dan Retribusi Daerah jo Peraturan Daerah Nomor 13 Tahun 2010 tentang Pajak Daerah. Atas dasar hal tersebut dipandang perlu melakukan penelitian berkenaan dengan implementasinya dalam praktek, terutama terkait dengan peranan PPAT dalam pembayaran BPHTB oleh Wajib Pajak dan akibat hukum terhadap PPAT yang menandatangani akta peralihan hak atas tanah dan/atau bangunan bekas hak milik adat, dan bagaimana keabsahan terhadap akta peralihan hak atas tanah dan/atau bangunan bekas hak milik adat tersebut.

Metode pendekatan penelitian yang digunakan bersifat yuridis empiris, pengumpulan data dilakukan secara primer dan sekunder, sehingga diperoleh pembahasan yang sistematis, yang selanjutnya dianalisis secara kualitatif.

Hasil penelitian mengungkapkan peranan PPAT dalam pembuatan akta peralihan hak atas tanah dan/atau bangunan bekas Hak Milik Adat berkaitan dengan Pembayaran Bea Perolehan Hak Atas Tanah dan/atau Bangunan Bekas hak Milik Adat di Kabupaten Magelang berperanan dalam membantu tugas Kantor Pajak Daerah guna mengamankan Penerimaan Daerah dari sektor Pajak Daerah yaitu BPHTB. Konsekuensi hukum terhadap akta peralihan hak atas tanah dan/atau bangunan bekas hak milik adat yang telah ditandatangani oleh PPAT sebelum dilaksanakannya pembayaran BPHTB atas peralihan hak atas tanah daniatau bangunan bekas hak milik adat tersebut dan sanksi hukum apa yang diberikan kepada PPAT tidak mempengaruhi keabsahan akta tersebut. Kata Kunci : PPAT, BPHTB, Tanah Bekas Hak Milik Adat.
\end{abstract}

\section{ABSTRACT}

BPHTB is a tax imposed on the transfer of rights to land and / or buildings, resulting in the transfer of rights to land and / or buildings from those who have rights to those who have rights to land and / or buildings, while land rights are referred to in Law Number 5 Year 1960 on Basic Regulation of Agrarian Principles. To prove the transfer of rights to land and / or buildings except the transfer of rights through auctions, as required by the BAL shall be proven by an authentic deed made by PPAT.As one of the Officials authorized to make a land / building title transfer deed, PPAT subject to the provisions of Article 91 paragraph (1) of Law Number 28 Year 2009 regarding Regional Tax and Regional Levy jo Local Regulation Number 13 Year 2010 on Regional Taxes. On the basis of this matter, it is deemed necessary to conduct research related to its implementation in practice, especially related to the role of PPAT in the payment of BPHTB by the Taxpayer and the legal effect on the PPAT signing the deed of transfer of land rights and / or the building of customary property rights, and how the legality deed of transfer of rights over the land and / or the former building of customary property rights.

The research method used is empirical juridical, data collection is done in primary and secondary, so that obtained a systematic discussion, which then analyzed qualitatively.

The result of the research reveals the role of PPAT in making the deed of transfer of rights to the land and / or the building of the former Customary Property in relation to the Payment of Acquisition of Land Ownership and / or Used Customary Rights in Magelang Regency to assist the Regional Tax Office duty to secure the Regional Revenue of the Regional Tax Sector ie BPHTB. Legal consequences to the deed of transfer of land rights and / or buildings of customary property rights that have been signed by PPAT prior to the implementation of the payment 
of BPHTB over the transfer of land rights and or the building of the former customary property rights and the legal sanction given to the PPAT does not affect the validity of the deed .

Keywords: PPAT, BPHTB, Land Used Indigenous Rights.

\section{PENDAHULUAN}

Pajak dan pemasukan negara yang bersifat memaksa sebagaimana yang dimaksudkan dalam Undang-Undang Dasar 1945 merupakan modal dan sumber pembiayaan bagi pembangunan negara. Oleh sebab itu mengenai hal ini harus mendapatkan pengaturan yang jelas dan dilaksanakan secara konsekuen serta diikuti dengan sanksi hukum yang mengikat dan memaksa untuk terjaminnya kelanjutan pembangunan nasional.

Pajak adalah iuran rakyat kepada kas negara berdasarkan undang-undang (yang dapat dipaksakan) dengan tiada mendapat jasa timbal balik (kontraprestasi), yang langsung dapat ditunjukan dan yang digunakan untuk membayar pengeluaran umum. ${ }^{1}$

Pajak adalah iuran kepada negara (yang dapat dipaksakan) yang terutang oleh wajib pajak yang pembayarannya menurut peraturan-peraturan dengan tidak mendapat prestasi kembali, yang langsung dapat ditunjuk, yang gunanya adalah untuk membiayai pengeluaran umum berhubung tugas negara menyelenggarakan pemerintah. ${ }^{2}$

Bea Perolehan Hak atas Tanah dan atau Bangunan dikenakan terhadap orang atau badan yang memperoleh hak atas tanah dan atau bangunan. Perolehan atas suatu hak atas tanah dan atau bangunan ini bisa diartikan bahwa orang atau badan tersebut mempunya nilai lebih atas tambahan atau perolehan hak tersebut. Dimana tidak semua orang mempunyai kemampuan lebih untuk mendapatkan tanah dan atau bangunan. ${ }^{3}$

Berkaitan dengan penerimaan negara yang berasal dari BPHTB, persoalan hukum tentang pajak merupakan persoalan masyarakat dan negara, khususnya elemen masyarakat yang merupakan wajib pajak dan mempunyai utang pajak yang harus dibayarkan ataupun utang lainnya kepada negara dalam bentuk BPHTB. Oleh sebab itu setiap anggota masyarakat seharusnya mengetahui hal-hal yang berkenaan dengan pajak, baik tentang asas pajak,

\footnotetext{
1 Rocmat Soemitro, Dasar-Dasar Hukum Pajak dan Pajak Pendapatan, (Bandung : Eresco, 1977), hlm.22

2 Djamaudin Gade dan Muhammad, Hukum Pajak, (Jakarta : Fakultas Ekonomi, Universitas Indonesia, 2004), hlm.7

${ }^{3}$ https://eddiwahyudi.com/perspektif-pajak-sebagai-saranapendukung-pembangunan/bea-perolehan-hak-atas-tanahdan-bangunan-bphtb/, akses internet tanggal 20 Oktober 2017
}

jenis atau macam-macam pajak, tata cara pembayaran pajak, hak dan kewajiban wajib pajak, serta upaya hukum dibidang perpajakan.

Peralihan hak atas tanah dikenakan biaya dan dibayarkan kepada negara. Bukti pembayaran ini menjadi salah satu syarat dan sekaligus merupakan bagian dari prosedur peralihan hak atas tanah serta pencatatannya secara adminstrasi di samping bagian dari tahapan dalam memenuhi asas publisitas. Artinya tanpa bukti pembayaran biaya tersebut, secara hukum dan admnistrasi peralihan hak atas tanah belum dapat dilaksanakan. Oleh sebab itu mengenai pembebanan biaya peralihan hak atas tanah ini harus diatur secara tegas dalam suatu peraturan perundang-undangan sebagai dasar pelaksanannya.

Sejak berlakunya Undang-undang Nomor 21 Tahun 1997 sebagaimana yang telah diubah dengan Undang-undang Nomor 20 tahun 2000 tentang Bea Perolehan Hak Atas Tanah dan Bangunan (UUBPHTB) dan Undang-Undang No.5 tahun 1960 tentang Peraturan Dasar Pokok-Pokok Agraria, maka hak-hak atas tanah Barat tidak berlaku lagi. Dengan demikian pungutan Bea Balik Nama atas pemindahan harta tetap berdasarkan hukum barat yaitu ordonansi Bea balik Nama menurut staatsblad 1924 Nomor 291 tidak dapat dilaksanakan.

Tugas pokok dan kewenangan dari PPAT sesungguhnya adalah sebagaimana disebutkan Pasal 2 ayat (10) dan (2) Peraturan Pemerintah No.37 Tahun 1998 tentang Peraturan Jabatan Pejabat Pembuat Akta Tanah, yaitu melaksanakan sebagian kegiatan pendaftaran tanah dengan membuat akta sebagaimana bukti telah dilakukannya perbuatan hukum tertentu mengenai hak atas tanah atau hak milik atas satuan rumah susun yang akan dijadikan dasar bagi pendaftaran perubahan data tanah yang diakibatkan oleh perbuatan hukum tersebut, yaitu jual beli, tukar menukar, hibah, pemasukan ke dalam perusahaan (inbreng), pembagian hak bersama, pemberian hak guna bangunan/hak pakai atas tanah hak milik, pemberian hak tanggungan, dan pemberian kuasa membebankan hak tanggungan.

Kewenangan tersebut bukan hanya berhubungan dengan penarikan BPHTB atas peralihan hak atas tanah akan tetapi juga dengan keabsahan pendaftaran peralihan atas tanah tersebut karena setelah PPAT menandatangani akta tentang peralihan tersebut, maka selambat-lambatnya 7 (tujuh) hari kerja sejak tanggal ditandatanganinya akta tersebut, PPAT wajib menyampaikan dan 
mendaftarkan akta yang dibuatnya berikut dokumendokumen terkait kepada kepala Kantor pertanahan setempat untuk memenuhi asas publisitas, sebagaimana diatur dalam Pasal 40 ayat (1) Peraturan Pemerintah No.24 Tahun 1997 tentang Pendaftaran Tanah.

Bagi PPAT yang membuat akta tanpa mengindahkan pembayaran BPHTB dari pihak terkait jelas akan menimbulkan persoalan hukum juga karena tindakan tersebut diancam dengan sanksi administrasi dari Direktorat Jenderal Pajak / Kantor Pelayanan Pajak Bumi dan Bangungan / Kantor Pajak Pratama, disamping sanksi dari Kantor Pertanahan.

Oleh sebab itu mengenai kewajiban pembayaran BPHTB dalam kontek ini menjadi penting dan menarik untuk diteliti serta sangat erat relevansinya dengan profesi PPAT, maka dilakukan suatu penelitian dan menyusunnya dalam tesis dengan topik "Peranan PPAT Dalam Pembuatan Akta Peralihan Hak Atas Tanah dan/atau Bangunan Bekas Hak Milik Adat Berkaitan Dengan Pembayaran Bea Perolehan Hak Atas Tanah dan/atau Bangunan".

Berdasarkan pembahasan pada latar belakang tersebut di atas, maka pokok permasalahan yang akan diteliti adalah sebagai berikut : 1) Bagaimana peran PPAT dalam pembuatan akta peralihan hak atas tanah dan/atau bangunan bekas Hak Milik Adat berkaitan dengan pembayaran Bea Perolehan Hak Atas Tanah dan/atau Bangunan ? 2) Bagaimana konsekuensi hukum terhadap akta peralihan hak atas tanah dan/atau bangunan bekas Hak Milik Adat yang telah ditandatangani oleh PPAT sebelum dilaksanakannya pembayaran BPHTB atas peralihan hak atas tanah dan/atau bangunan tersebut dan sanksi hukum apa yang diberikan kepada PPAT? 3) Kendala-kendala apa yang dihadapi oleh PPAT dalam pembuatan akta peralihan hak atas tanah dan/atau bangunan bekas Hak Milik Adat dihubungkan dengan BPHTB dan upaya mengatasinya ?

\section{HASIL PENELITIAN DAN PEMBAHASAN}

\section{Peran PPAT dalam pembuatan akta peralihan hak atas tanah dan/atau bangunan bekas Hak Milik Adat berkaitan dengan pembayaran Bea Perolehan Hak Atas Tanah dan/atau Bangunan}

Di Kabupaten Magelang masih banyak tanah yang belum dibuatkan sertipikat, artinya tanah-tanah di daerah tersebut bukti kepemilikannya masih banyak dengan letter $\mathrm{C}$ atau dalam Praktek disebut dengan Girik secara teorits tanah-tanah disebut Bekas Hak Milik Adat. Dalam prakteknya tanah bekas hak milik adat sudah dapat beralih dan dialihkan dengan bukti Peralihan hak atas tanah dan/atau bangunan di hadapan PPAT, misalnya secara jual beli, hibah dan pembagian hak bersama.

Dalam kehidupan masyarakat Kabupaten Magelang dimana, bukti kepemilikan hak atas tanah dan/atau bangunan Bekas Hak Milik Adat (Girik) terdapat dua (2) macam, yaitu:

1) Girik Milik adat.

Girik Milik Adat adalah yaitu: tanah-tanah yang dikuasai oteh pribumi yang telah didaftarkan sebelum dan sesudah tahun 1945, tanah tersebut pada umumnya di atas tanah hak barat dan memang dari semula telah dikuasai oleh pribumi, dan kemudian apabila didaftarkan ke Kantor Badan Pertanahan Nasional dapat diterbitkan sertipikatnya menjadi hak milik.

2) Girik Partikelir.

Girik partikelir yaitu : tanah-tanah yang dikuasai oleh pribumi yang berada di atas tanah partikelir (tuan tanah), dan dahulu telah didaftar pada kantor pajak bumi dan bangunan, baik di atas tanah usaha, tanah tionghoa, tanah hak erfpacht, yang telah menjadi tanah negara semenjak berlakunya Undang-undang Nomor 1 Tahun 1958 tentang Penghapusan Tanah-tanah Partikelir, apabila dimohonkan haknya maka dapat diberikan hak pakai sesuai dengan Peraturan Menteri Dalam Negeri Nomor 5 tahun 1973 tentang Ketentuanketentuan Tata Cara Pemberian Hak atas Tanah jo Peraturan Menteri Dalam Negeri Nomor 6 tahun 1972 tentang Pelimpahan Wewenang Pemberian Hak atas Tanah.

Dalam perolehan hak atas tanah dan/atau bangunan itu melalui proses peralihan hak atas tanah dan/atau bangunan dengan melakukan perbuatan hukum, yaitu dengan pembuatan akta peralihan hak atas tanah dan/atau bangunan di hadapan PPAT, sebagai Pejabat Umum.

Berhubungan dengan peralihan hak atas tanah dan/atau bangunan bekas hak milik adat yang dibuatkan akta peralihan hak atas tanah dan /atau bangunan oleh PPAT, maka peralihan hak atas tanah dan/atau bangunan bekas hak milik adat telah di kenakan BPHTB artinya apabila warga negara Indonesia melakukan peralihan hak atas tanah dan atau/ bangunan bekas hak milik adat maka pihak yang memperoleh hak atas tanah dan/atau bangunan tersebut sudah dikenakan BPHTB.

Pembuatan akta peralihan hak atas tanah dan/atau bangunan bekas hak milik adat di hadapan PPAT telah sesuai dengan Peraturan Pemerintah Nomor 24 Tahun 1997 tentang Pendaftaran tanah jo Peraturan Pemerintah Nomor 24 Tahun 2016 tentang Peraturan Pejabat Pembuat Akta Tanah, yaitu: Bahwa PPAT adalah Pejabat umum yang diberi kewenangan membuat akta akta tanah. 
Dalam prakteknya di Kabupaten Magelang terdapat akta peralihan hak atas tanah dan/atau bangunan bekas hak milik adat yang ditandangani oleh PPAT tanpa Wajib Pajak melakukan kewajiban pembayaran BPHTB.

Pembuatan akta peralihan hak atas tanah dan/atau bangunan bekas hak milik adat yang ditandatangani oleh PPAT tanpa melakukan kewajiban pembayaran BPHTB tersebut, dilakukan atas permintaan para pihak, dalam hal ini PPAT meminta terlebih dahulu surat pernyataan dari para Wajib Pajak, bahwa: Wajib Pajak akan melakukan kewajiban pembayaran BPHTB pada saat pendaftaran hak atas tanah dan/atau bangunan ke Kantor Badan Pertanahan Nasional, dan Wajib Pajak tidak akan menuntut dan melibatkan PPAT apabila ada tagihan pembayaran BPHTB yang terutang, dikarenakan belum dibayarnya BPHTB dari Wajib Pajak yang memperoleh hak atas tanah dan/atau bangunan oleh Kantor Pajak Daerah dan Retribusi Daerah atau Kantor Badan Pertanahan Nasional.

Dalam pembuatan akta peralihan hak atas tanah dan/atau bangunan bekas hak milik adat tanpa melakukan pembayaran BPHTB, dimana akta peralihan hak atas tanah dan/atau bangunan bekas hak milik adat yang telah dibuatkan oleh PPAT, maka secara hukum telah terjadi peralihan hak atas tanah dan/atau bangunan bekas hak milik adat artinya peralihan hak atas tanah dan/atau bangunan bekas hak milik adat telah beralih dari pemilik pertama kepada pemilik yang memperolehnya, dengan dibuktikan akta peralihan hak atas tanah dan/atau bangunan yang telah ditandatangani oleh PPAT sebelum Wajib Pajak melakukan kewajiban pembayaran BPHTB.

Penandatanganan akta peralihan hak atas tanah dan/atau bangunan bekas hak milik adat tanpa melakukan pembayaran BPHTB tersebut oleh PPAT, maka sudah tidak sesuai dengan ketentuan yang diamanatkan oleh Pasal 91 ayat (1) UndangUndang Nomor 28 Tahun 2009 tentang Pajak Daerah dan Retribusi Daerah jo Peraturan Daerah Nomor 13 Tahun 2010 tentang Pajak Daerah, artinya : penandatanganan akta peralihan hak atas tanah dan/atau bangunan bekas hak milik adat tersebut PPAT telah melanggar ketentuan dari Pasal 91 ayat (1) Undang-Undang Nomor 28 Tahun 2009 tentang Pajak Daerah dan Retribusi Daerah jo Peraturan Daerah Nomor 13 Tahun 2010 tentang Pajak Daerah, dimana PPAT telah menandatangani akta peralihan hak atas tanah dan/atau bangunan bekas hak milik adat tanpa Wajib Pajak memperlihatkan bukti Pembayaran BPHTB terlebih dahulu.
Lebih lanjut dikatakan PPAT biasanya hanya membantu penghitungan dan kadang-kadang membantu menyetorkannya ke Kas Daerah. Biasanya hal itu dilakukan apabila wajib pajak menyerahkan pengurusan pembayaran Bea Perolehan Hak atas Tanah dan/atau Bangunan dari perolehan hak atas tanah dan/atau bangunan yang diterimanya kepada PPAT. ${ }^{4}$

Apabila tanah dan/atau bangunan tersebut telah terdaftar akan tetapi belum memiliki Sertipikat Hak atas Tanah, maka sebagai penggantian dari sertipikat Hak atas Tanah dan/atau Bangunan tersebut adalah Surat Keterangan Pendaftaran Tanah (SKPT) atas tanah dan/atau bangunan yang dibuat dan diterbitkan oleh Kantor Pertanahan Kabupaten/Kota, yang isinya menerangkan bahwa hak atas tanah dan/atau bangunan tersebut belum memiliki Sertipikat Hak Atas Tanah.

Bagi PPAT yang menandatangani akta peralihan hak atas tanah dan/atau bangunan tanpa wajib pajak menyerahkan bukti pembayaran BPHTB terlebih, jelas akan menimbulkan persoalan hukum dan karena tindakan tersebut diancam dengan sanksi administrasi berdasarkan ketentuan UndangUndang Nomor 28 Tahun 2009 tentang Pajak Daerah.

Untuk menguatkan peranan Pejabat Pembuat Akta Tanah/Notaris sebagai pihak yang mengawal atas kewajiban pemenuhan Bea Perolehan Hak atas Tanah dan/atau Bangunan (BPHTB) oleh wajib pajak, Undang-Undang Nomor 28 Tahun 2009 tentang Pajak dan Retribusi Daerah jo Peraturan Daerah Nomor 13 Tahun 2010 tentang Pajak Daerah juga memberikan sanksi kepada Pejabat Pembuat Akta Tanah/Notaris apabila Pejabat Pembuat Akta Tanah/Notaris melanggar ketentuan sebagaimana dimaksud Pasal 91 ayat (1) jo Pasal 14 ayat (1) berupa denda sebesar Rp. 7.500.000,00 (tujuh juta lima ratus ribu rupiah) untuk setiap pelanggaran apabila Pejabat Pembuat Akta Tanah/Notaris menandatangani akta pemindahan hak atas tanah dan/atau bangunan pada saat Wajib Pajak belum menyerahkan bukti pembayaran pajak berupa Surat Setoran Pajak Daerah Bea Perolehan Hak atas Tanah dan / atau Bangunan (SSPDBPHTB), sebagaimana yang diatur dalam Pasal 93 ayat (1) Undang-Undang Nomor 28 Tahun 2009 tentang Pajak Daerah dan Retribusi Daerah jo Peraturan Daerah Nomor 13 Tahun 2010 tentang Pajak Daerah.

Berdasarkan uraian tersebut di atas, maka salah satu syarat dalam peralihan hak atas tanah

\footnotetext{
4 Wawancara, dengan Pejabat Pembuat Akta Tanah di Wilayah Kabupaten Magelang.
} 
dan/atau bangunan menurut hukum yang berlaku adalah adanya bukti pembayaran BPHTB, artinya apabila warga negara Indonesia melakukan peralihan hak atas tanah dan/atau bangunan dengan pembuatan akta peralihan hak atas tanah dan/atau bangunan tersebut di hadapan PPAT maka secara hukum peralihan hak atas tanah dan/atau bangunan tersebut sudah dikenakan BPHTB, baik tanah yang sudah bersertipikat maupun tanah yang belum bersertipikat (Bekas Milik Adat, dalam praktek sering disebut dengan Girik).Akan tetapi dalam praktek dapat saja terjadi persoalan karena penandatanganan akta peralihan hak atas tanah dan/atau bangunan telah dilakukan sebelum dibayarkan BPHTB termasuk di Kabupaten Magelang.

Setelah dilakukan pembayaran BPHTB oleh wajib pajak, maka bukti pembayaran tersebut diperlihatkan kepada PPAT, dan PPAT tersebut telah boleh melakukan penandatanganan akta peralihan hak atas tanah dan/atau bangunan.

Dalam hal ini tugas PPAT bukan hanya selesai pada saat pembayaran BPHTB oleh Wajib Pajak, tetapi harus dilakukan pelaporan bukti pembayaran BPHTB tersebut kepada Kantor Penerimaan Pajak Daerah (Dispenda), dalam hal ini Kantor Pajak Daerah akan melakukan penelitian terhadap bukti pembayaran BPHTB tersebut.

Peranan dari Pejabat Pembuat Akta Tanah (PPAT) dalam hal Wajib Pajak melakukan kewajiban pembayaran BPHTB adalah semua tahapan yang dilalui oleh wajib pajak Bea Perolehan Hak Atas Tanah dan/atau Bangunan dalam melakukan penghitungan dan pembayaran Bea Perolehan Hak atas Tanah dan/atau Bangunan, peranan dari Pejabat Pembuat Akta Tanah (PPAT) dalam pemenuhan pembayaran Bea Perolehan Hak atas Tanah dan/atau Bangunan hanya sebagai pihak yang menjembatani pembayaran Bea Perolehan Hak Atas Tanah dan/atau Bangunan. ${ }^{5}$

Sehubungan dengan adanya perolehan hak atas tanah dan/ atau bangunan dengan sendirinya wajib pajak tersebut akan melakukan peralihan hak atas hak atas tanah dan/atau bangunan yang diperolehnya, baik tanah yang sudah bersertipikat maupun tanah dan/atau bangunan yang belum bersertipikat. Salah satu syarat untuk dapat melakukan peralihan hak atas tanah dan/atau bangunan, selain pembuatan akta peralihan hak atas tanah dan/atau bangunan yang dilakukan oleh Pejabat Pembuat Akta Tanah juga wajib pajak telah melunasi atau membayar Bea Perolehan Hak atas

\footnotetext{
${ }^{5}$ Wawancara, dengan Pejabat Pembuat Akta Tanah di Wilayah Kabupaten Magelang.
}

Tanah dan/atau Bangunan (BPHTB) atas peralihan hak atas tanah dan/atau bangunan. Maksudnya Pejabat Pembuat Akta Tanah tidak akan menandatangani akta peralihan hak atas tanah dan/atau bangunan yang diperoleh oleh wajib pajak sebelum wajib pajak yang bersangkutan melunasi kewajibannya yaitu membayar Bea Perolehan Hak atas Tanah dan/atau Bangunan (BPHTB) ke Kas Daerah.

Sahnya perbuatan hukum yang dilakukan ditentukan oleh terpenuhinya syarat-syarat materiil yang bersangkutan, yaitu kecakapan dan kewenangan para pihak untuk melakukan perbuatan hukum tersebut, untuk melakukan perbuatan hukum telah dipenuhi syarat terang, tunai dan riil bagi perbuatan hukum peralihan hak yang dilakukan. ${ }^{6}$

Dengan demikian dengan ditandatangani akta peralihan hak atas tanah dan/atau bangunan bekas hak milik adat di hadapan PPAT, oleh para pihak, saksi-saksi, maka peralihan hak atas tanah dan/atau bangunan bekas hak milik adat dianggap sah dan dengan demikian telah terjadi peralihan hak kepemilikan atas tanah dan/atau bangunan bekas hak milik adat tesebut dari pihak yang mempunyai hak kepada pihak yang memperoleh hak atas tanah dan/atau bangunan bekas hak milik adat.

\section{Konsekuensi hukum terhadap akta peralihan hak atas tanah dan/atau bangunan bekas Hak Milik Adat yang telah ditandatangani oleh PPAT sebelum dilaksanakannya pembayaran BPHTB atas peralihan hak atas tanah dan/atau bangunan tersebut dan sanksi hukum apa yang diberikan kepada PPAT}

Dalam praktek di Kabupaten Magelang terdapat penandatanganan akta peralihan hak atas tanah dan/atau bangunan bekas hak milik adat oleh PPAT tanpa Wajib Pajak melakukan kewajiban pembayaran Bea Perolehan Hak atas Tanah dan/atau Bangunan terlebih dahulu.

Jika terjadi keadaan tersebut, maka akan menimbulkan permasalahan bagi PPAT yang telah membuat akta peralihan hak atas tanah dan/atau bangunan bekas hak milik adat tersebut, dengan akibat adanya sanksi administrasi dari Pemerintah Daerah qq. Kantor Pelayanan Pajak Daerah dan Retribusi Daerah, di samping sanksi dari Kantor Pertanahan, permasalahan lain yang akan timbul terkait dengan keabsahan dari akta peralihan hak

\footnotetext{
6 Boedi Harsono, Makalah, Seminar tentang Pendaftaran Tanah Di bidang Hak Tanggungan Tanah dan PPAT (Jakarta : Badan Pertanahan Nasional, Deputi Bidang Pengukuran Dan Pendaftaran, 1990), hlm 518-519
} 
atas tanah dan/latau bangunan bekas hak milik adat yang telah dibuat oleh PPAT yang bersangkutan.

Penandatanganan akta peralihan hak atas tanah dan/atau bangunan bekas hak milik adat yang dibuat oleh PPAT, belum melakukan kewajiban pembayaran BPHTB, selain menimbulkan akibat hukum bagi PPAT yang bersangkutan juga berpengaruh terhadap keabsahan akta peralihan hak atas tanah dan/atau bangunan bekas hak milik adat yang dibuat oleh PPAT yang bersangkutan. Sebagaimana yang telah diuraikan sebelumnya bahwa untuk membuktikan adanya perbuatan hukum peralihan hak atas tanah dan/atau bangunan haruslah dibuat akta otentik oleh Pejabat yang berwenang yaitu PPAT.

Hal ini untuk memberi kepastian hukum bagi pihak yang memperoleh hak atas tanah dan/atau bangunan bekas hak milik adat tersebut sehingga pihak yang memperoleh hak atas tanah dan/atau bangunan bekas hak milik adat dapat mempertahankan hak atas tanah dan/atau bangunan bekas hak milik adat tersebut dari gugatan pihak manapun.

Terhadap akta peralihan hak atas tanah dan/atau bangunan bekas hak milik adat yang ditandatangani tanpa melakukan kewajiban pembayaran BPHTB adalah; akta peralihan hak atas tanah dan/atau bangunan bekas hak milik adat tersebut tetap sah sepanjang dibuat oleh Pejabat yang berwenang sesuai dengan peraturan perundang-undangan, dan pada prinsipnya perbuatan hukum yang dilakukan oleh para pihak dalam akta sudah sah dan mengikat bagi kedua belah pihak dengan ditandatanganinya akta peralihan hak atas tanah dan/atau bangunan bekas hak milik adat tersebut oleh para pihak, saksi-saksi dan PPAT. ${ }^{7}$

Mengenai pemberian sanksi administrasi dan denda dalam hal penandatanganan akta peralihan hak atas tanah dan/atau bangunan bekas hak milik adat tanpa meiaksanakan kewajiban pembayaran BPHTB adalah merupakan kewenangan dari Kantor Dinas Pengelolaan Keuangan dan Aset Daerah atau Pemerintah Daerah Kabupaten Magelang sesuai dengan ketentuan Pasal 93 ayat (1) UndangUndang Nomor 28 Tahun 2009 tentang Pajak Daerah, sehingga Kantor Pertanahan Nasional Kabupaten Magelang tidak memberikan sanksi kepada PPAT yang bersangkutan.

Hal ini berbeda dengan pelanggaran terhadap salah satu ketentuan yang diatur dalam Pasal 39 ayat (1) huruf $g$ Peraturan Pemerintah Nomor 24 Tahun 1997 Tentang Pendaftaran Tanah yaitu PPAT

\footnotetext{
7 Wawancara dengan, staf Kantor Pertanahan Kabupaten Magelang.
}

menolak untuk membuat akta peralihan hak atas tanah dan/atau bangunan, jika tidak dipenuhi syarat lain atau dilanggar larangan yang ditentukan dalam peraturan perundang-undangan yang bersangkutan. Misalnya larangan membuat akta peralihan hak atas tanah dan/atau bangunan sebelum diserahkan kepada Pejabat Pembuat Akta Tanah tanda bukti fotocopy Surat Setoran Pajak Daerah BPHTB sebagaimana diatur dalam Undang-undang Nomor 28 Tahun 2009 tentang Pajak Daerah dan Retribuis Daerah. $^{8}$

Apabila PPAT tidak meminta bukti pembayaran BPHTB dalam arti kewajiban pembayaran BPHTB tidak dibayarkan sama sekali, maka PPAT yang bersangkutan akan dikenakan tindakan administrasi oleh Kantor Badan Pertanahan Kabupaten Magelang, sebagaimana diatur dalam Peraturan Pemerintah Nomor 24 Tahun 1997 tentang Pendaftaran Tanah yang berupa teguran tertulis sampai pemberhentian dari jabatannya sebaqai PPAT, dengan tidak mengurangi kemungkinan dituntut ganti kerugian oleh pihak-pihak yang meaderita kerugian yang diakibatkan dan diabaikannya ketentuan-ketentuan tersebut. ${ }^{9}$

Kendala-kendala yang dihadapi oleh PPAT dalam Pembuatan Akta Peralihan Hak atas Tanah dan/atau Bangunan Bekas Hak Milik Adat dihubungkan dengan BPHTB dan Upaya Mengatasinya.

Berdasarkan penelitian yang dilakukan di Kantor Dinas Pengelolaan Keuangan dan Aset Daerah Kabupaten Magelang dan terhadap wajib pajak, maka dapat kelompokkan kendala yang ada dan ditemukan di lapangan, yaitu :

1) Kendala yang berhubungan wajib pajak lebih disebabkan oleh kekurangtahuan dari para wajib pajak tersebut terhadap aturan hukum yang berlaku, terutama di bidang Pajak BPHTB. Berdasarkan keadaan tersebut terlihat, bahwa para wajib pajak dengan sendirinya mengalami kendala/kesulitan dalam melakukan perhitungan terhadap Bea Perolehan Hak atas Tanah dan/atau Bangunan yang harus dibayarkannya atas peralihan hak atas tanah dan/atau bangunan yang dilakukannya.

2) Hambatan yang berhubungan dengan peran dari Pejabat Pembuat Akta Tanah. Sebagaimana yang telah diterangkan sebelumnya dalam sub bab sebelumnya bahwa pelaksanaan pembayaran Bea Perolehan Hak atas Tanah dan/atau Bangunan berkaitan erat dengan

\footnotetext{
${ }^{8}$ Loc. cit.

${ }^{9}$ Budi Harsono.op.cit hlm 512-513
} 
Pejabat Pembuat Akta Tanah (PPAT). Diantaranya adalah dimana Pejabat Pembuat Akta Tanah/Notaris harus menjelaskan, menghitung dan membantu untuk terlaksananya pembayaran BPHTB. Kendala yang sering terjadi pada penghitungan BPHTB oleh Pejabat Pembuat Akta Tanah adalah tidak sesuainya data SPPT PBB yang diterima oleh PPAT dari Wajib Pajak dengan data yang ada pada Kantor Pajak Daerah atau Retribusi Daerah, turutama tentang luas tanah dan luas bangunan sebagai obyek BPHTB, karena masyarakat tidak melaporkan terhadap adanya perbedaan dan perubahan luas tanah dan/atau bangunannya kepada Kantor Pajak Daerah dan Retribusi Daerah. Dan PPAT harus menandatangani SSPD (Surat Setoran Bea Perolehan Hak Atas Tanah dan Bangunan) setelah wajib pajak melakukan pembayaran atas Bea Perolehan Hak atas Tanah dan /atau Bangunan-nya kepada bank yang ditunjuk oleh Perrierintah Daerah, guna untuk melakukan pelaporan bukti Pembayaran SSPD BPHTB tersebut.

\section{PENUTUP}

Berdasarkan uraian dan bahasan pada babbab sebelumnya, maka dapat di simpulkan hal-hal sebagai berikut :

1. Peranan PPAT dalam pembuatan akta peralihan hak atas tanah dan/atau bangunan bekas Hak Milik Adat berkaitan dengan Pembayaran Bea Perolehan Hak Atas Tanah dan/atau Bangunan Bekas hak Milik Adat di Kabupaten Magelang berperanan dalam membantu tugas Kantor Pajak Daerah guna mengamankan Penerimaan Daerah dari sektor Pajak Daerah yaitu BPHTB, dan Peranan PPAT lebih kepada pengawal terlaksananya pemenuhan pembayaran Bea Perolehan Hak atas Tanah dan/atau Bangunan Bekas Hak Milik Adat karena PPAT merupakan pejabat yang akan melegalkan peraiihan hak atas tanah dan/atau bangunan bekas hak milik adat, dengan kata lain, setiap perbuatan hukum menyangkut peralihan hak atas tanah dan/atau bangunan aktanya akan dibuat oleh seorang PPAT sebagaimana yang telah diamanatkan oleh Peraturan Perundang-undangan yang menyangkut masalah Pertanahan.

2. Konsekuensi hukum terhadap akta peralihan hak atas tanah dan/atau bangunan bekas hak milik adat yang telah ditandatangani oleh PPAT sebelum dilaksanakannya pembayaran BPHTB atas peralihan hak atas tanah daniatau bangunan bekas hak milik adat tersebut dan sanksi hukum apa yang diberikan kepada PPAT tidak mempengaruhi keabsahan akta tersebut.

3. Kendala-kendala yang dihadapi oleh PPAT dalam Pembuatan akta peratihan hak atas tanah dan/atau bangunan bekas hak milik adat dihubungkan dengan BPHTB adalah :

a. Kurangnya informasi dan sosialisasi mengenai peraturan-peraturan BPHTB yang terus berkembang;

b. Tidak sesuai data-data yang diberikan oleh Wajib Pajak kepada PPAT dengan data yang ada pada obyek BPHTB, baik mengenai luas tanah maupun mengenai luas bangunan.

c. Apabila peralihan hak atas tanah dan/atau bangunan dilakukan di awal tahun, maka penentuan NJOP PBB belum diketahui oleh Wajib Pajak, maka PPAT harus menanyakan kepada Kantor Pelayanan Pajak Daerah.

d. Di tetapkannya waktu dan tempat pembayaran untuk melakukan penyetoran BPHTB. Kendala tersebut dirasakan sangat menghambat proses peralihan hak atas tanah dan/atau bangunan bekas hak milik adat karena apabila BPHTB belum dapat dibayar karena adanya pembatasan waktu dan tempat tertentu untuk melakukan pembayaran BPHTB. Dengan adanya kendala tersebut maka akta peralihan hak atas tanah dan/atau bangunan bekas hak milik adat tidak dapat dilakukan dihadapan PPAT.

Adapun cara mengatasi hambatan tersebut adalah sebagai berikut:

a. Pemerintah Daerah membuat program sosialisasi setiap tahun yang dilaksanakan dengan penyerahan SPPT PBB kepada masyarakat.

b. Pemerintah Daerah mencetak lebih awal SPPT PBB pada awal tahun dan segera membagikan lebih awal dari Pemerintah Daerah kepada Wajib Pajak.

c. Pemerintah Daerah mengadakan koordinasi antara Badan Pertanahan Nasional (BPN) setempat dengan Dinas Pengelolaan Keuangan dan Aset Kabupaten Magelang termasuk organisasi IPPAT, mengenai apabila perubahan peraturan tentang BPHTB.

d. Terhadap wajib pajak (klien), PPAT selalu memberikan penyuluhan mengenai perkembangan peraturan BPHTB, sehingga wajib pajak (klien) mengetahui perkembangan peraturan BPHTB apabila terjadi perubahan;

\section{DAFTAR PUSTAKA}

Boedi Harsono, Makalah, Seminar tentang Pendaftaran Tanah Di bidang Hak 
Tanggungan Tanah dan PPAT (Jakarta : Badan Pertanahan Nasional, Deputi Bidang Pengukuran Dan Pendaftaran, 1990),

Djamaudin Gade dan Muhammad, 2004, Hukum Pajak, Jakarta : Fakultas Ekonomi, Universitas Indonesia

Rocmat Soemitro, 1977, Dasar-Dasar Hukum Pajak dan Pajak Pendapatan, Bandung : Eresco
Wawancara, dengan Pejabat Pembuat Akta Tanah di Wilayah Kabupaten Magelang.

https://eddiwahyudi.com/perspektif-pajak-sebagaisarana-pendukung-pembangunan/beaperolehan-hak-atas-tanah-dan-bangunanbphtb/, akses internet tanggal 20 Oktober 2017 